\title{
Recent aspects of stored product entomology in New Zealand
}

\author{
K. G. SOMERFIELD \\ Plant Health Diagnostic Station, Ministry of Agriculture and Fisheries, \\ P.O. Box 24, Lincoln, New Zealand
}

\begin{abstract}
Stored-product insect problems in New Zealand since 1970, and interceptions at quarantine since 1955 of potentially important species, are reviewed. Reesa vespulae (Milliron) and Sphaericus gibboides Boieldieu have recently been reported from New Zealand for the first time. Quarantine interceptions of potentially important species include Bruchus pisorum (L.), Trogoderma granarium Everts, $T$. variabile Ballion, and Anthrenus flavipes LeConte. During the 1970s insect (and mite) contamination of dried milk products occurred after long periods of storage. In North Island poultryhouses mature larvae of Dermestes maculatus de Geer damaged structural timbers, and Alphitobius diaperinus Panzer occurred frequently and sometimes damaged polystyrene insulation. Hofmannophila pseudospretella (Stainton) larvae attacked carpets (many less than 6 years old), and after news media publicity 250 complaints of moth attack (72\% due to $H$. pseudospretella) were reported to the New Zealand Wool Board from 8 November 1979 to 29 February 1980.
\end{abstract}

Keywords Coleoptera; Lepidoptera; stored products; quarantine; dried milk products; animal housing; carpets; insect control; insect dispersal; insect pests; resistant insects; Reesa vespulae; Sphaericus gibboides; Bruchus pisorum; Trogoderma granarium; Trogoderma variabile; Anthrenus flavipes; Dermestes maculatus; Alphitobius diaperinus; Hofmannophila pseudospretella; Dermestidae; Ptinidae; Bruchidae; Tenebrionidae

NEW RECORDS AND QUARANTINE INTERCEPTIONS OF STORED-PRODUCT INSECTS

New records

Reesa vespulae (Milliron) (Col.: Dermestidae)

Waller \& Watt (1979) give the first record of this parthogenetic beetle from New Zealand. Dermestid larvae found infesting dried insects in the Entomology Department, Lincoln College were reared and adults emerged in July 1970; the species was identified as Reesa vespulae by Mrs E. R. Peacock, British Museum. A thorough search was made, but no further specimens have occurred at Lincoln College since the original discovery.

Dr J. C. Watt, Entomology Division, DSIR states (pers.comm.), that further specimens of $R$. vespulae have since been discovered amongst unidentified Dermestidae in the New Zealand Arthropod Collection, DSIR, Auckland, as follows:

Received 11 November 1980; revision 30 April 1981
Nelson, NN, 28 Jan 1942, A. Hamilton (3 specimens); Christchurch, MC, 16 Jan 1969, larva in "Arawa" wheat, STS 69/47221 (1 specimen, plus larval exuviae); Cromwell, $\mathrm{CO}$, in motel, 18-27 Nov 1974, J. C. Watt (1 specimen).

These widespread records indicate that the species is established in the South Island, although it is apparently not common.

$R$. vespulae has been recorded infesting dried insects and herbarium specimens and as a domestic pest in California (Waller \& Watt 1979). Since 1960 it has been recorded as a domestic, seed store, and museum pest in several European and other Northern Hemisphere countries (Adams 1978).

Sphaericus gibboides Boieldieu (Col.: Ptinidae)

Large numbers of this species occurred in ground coriander in a butcher's shop at Rotorua on 5 May 1972 (Manson and Richardson, pers. comms). Specimens were forwarded by Mr R. Zondag, Entomologist, Forest Research Institute, Rotorua, to Levin Plant Health Diagnostic Station for identification. S. gibboides has since occurred in dried herbs 
TABLE 1 - Quarantine interceptions of some stored-product Coleoptera (1955-1979 inclusive).

\begin{tabular}{|c|c|c|}
\hline Species & Host & $\begin{array}{l}\text { Country of origin } \\
\text { (Date of interception } \\
\text { where available) }\end{array}$ \\
\hline $\begin{array}{l}\text { BRUCHIDAE: } \\
\text { Bruchus pisorum (L.) }\end{array}$ & $\begin{array}{l}\text { Vicia faba } \text { L. (broad bean) (seeds) } \\
\text { Pisum sativum L. (garden pea) (seeds) } \\
\text { Pisum sativum L. (seeds) } \\
\text { Pisum sativum L. (seeds) }\end{array}$ & $\begin{array}{l}\text { Japan }(14-X-70) \\
\text { Italy }(10-X I-72) \\
\text { Japan }(17-X-77) \\
\text { U.S.A. }(22-I X-78)\end{array}$ \\
\hline $\begin{array}{l}\text { DERMESTIDAE: } \\
\text { Anthrenus flavipes Le Conte }\end{array}$ & $\begin{array}{l}\text { Car upholstery } \\
\text { Unknown } \\
\text { Feathers } \\
\text { Packing }\end{array}$ & $\begin{array}{l}\text { Malaya } \\
\text { India } \\
\text { India } \\
\text { U.S.A (2 interceptions) }\end{array}$ \\
\hline Trogoderma granarium Everts & $\begin{array}{l}\text { Agave sisalana Perrine (sisal) } \\
\text { Arachis hypogaea } \text { L. (peanut) } \\
\text { Effects } \\
\text { Foodstuffs } \\
\text { Foodstuffs } \\
\text { Pulses } \\
\text { Tent } \\
\text { Carpet } \\
\text { Sweepings }\end{array}$ & $\begin{array}{l}\text { South Africa } \\
\text { South Africa (3 interceptions) } \\
\text { Rhodesia } \\
\text { India } \\
\text { South Africa } \\
\text { Fiji } \\
\text { U.S.A. } \\
\text { India (1974) } \\
\text { Unknown (1975) }\end{array}$ \\
\hline Trogoderma variabile Ballion & $\begin{array}{l}\text { Medicago sativa L. (lucerne) (seeds) } \\
\text { Herbs } \\
\text { Cuminum cyminum } \text { L. (cumin) (seeds) } \\
\text { Helianthus annuus } \text { L. (sunflower) (seeds) }\end{array}$ & $\begin{array}{l}\text { U.S.A. (12-IX-77) } \\
\text { Greece (22-IX-77) } \\
\text { Iran (7-II-79) } \\
\text { Canada (6-IX-79) }\end{array}$ \\
\hline
\end{tabular}

at Auckland, in stored milk powder at Hamilton, and at Taupo and Wellington (Manson pers. comm.)

Dr J. C. Watt (pers. comm.) supplies the following additional records from the N.Z. Arthropod Collection, DSIR, Auckland: Nelson, NN, 2 Apr 1971, A. Joss, ex sodium bicarbonate (12 specimens); Christchurch, MC, 5 Jun 1980, S. Briesemann, in paprika supplied from North Island (3 specimens). Voucher specimens of the Rotorua and Hamilton records above are also represented in the collection.

Aitken (1975) recorded interceptions of $S$. gibboides from herbs and almonds. Papp (1962) stated that in California it had occurred in caraway seeds, red pepper, herbaria, and insect collections.

\section{Quarantine interceptions \\ Bruchus pisorum (F.) (Col.: Bruchidae)}

$B$. pisorum is regarded as an important potential pest of peas in New Zealand. It has occurred several times within the country, but so far has not established. In September 1973, New Zealand 'Greenfeast' peas grown and stored during the winter at Irwell, Canterbury were found during hand threshing to be infested with $B$. pisorum (identified by Dr G. Kuschel, Entomology Division, DSIR).

The crop had been grown next to imported North American lines and cross-infestation probably occurred (Somerfield 1977). The storage premises were fumigated, and there have been no further indications of $B$. pisorum at this locality. Live $B$. pisorum occurred in imported Italian peas at Pukeuri (near Oamaru) in November 1972. Two dead speci- mens were found in a seed store in Christchurch at about this time, and probably came from a line of imported peas planted at Waikari, North Canterbury in 1971 or 1972 . The crop grew poorly and was ploughed under before reaching maturity.

Most interceptions at quarantine of Bruchus pisorum have been made from peas (Pisum sativum L.) (Table 1).

Anthrenus flavipes LeConte (Col.: Dermestidae)

$A$. flavipes has been intercepted entering New Zealand on car upholstery, feathers, packing, and an unknown host (Table 1). This species is very destructive to upholstered furniture (Hatch 1961), and in tropical and subtropical regions, particularly the Orient, $A$. flavipes is a destructive household pest, the larvae damaging wool, fur, skins, and other materials of animal origin (Aitken 1975).

Mroczkowski (1968) stated that A. flavipes was "nearly cosmopolitan" while Aitken (1975) said that its distribution was "throughout the warm regions of the world", and that the geographic range of this species is limited by the susceptibility of the pupal stage to low temperatures, although the larvae are able to survive for long periods at sub-zero temperatures. Larval development is completed within the range $20^{\circ}-35^{\circ} \mathrm{C}$.

It is possible that $A$. flavipes would survive in New Zealand in heated factories, stores, and houses. It could be a pest of carpets and other woollen materials, and perhaps be a contaminant in milk powder production and storage areas, as well as attacking its usual overseas hosts. 
Trogoderma granarium Everts (Col.: Dermestidae)

Khapra beetle has traditionally been regarded as one of the most important potential pests of stored products in New Zealand. It is frequently a pest in tropical and subtropical countries, but little assessment has been made of its likely status in the temperate climate of New Zealand. It has been suggested that if it did establish it could be most important in the northern half of the North Island where winter temperatures are mildest.

Climatically $T$. granarium really needs periods at $30^{\circ} \mathrm{C}$, but localities with periods over $20^{\circ} \mathrm{C}$ may be at some risk, and indoor temperatures must be considered (Dr R. W. Howe, Slough Laboratory, England, pers. comm.). Howe (1957) referring to U.S. meteorological records states that $T$. granarium " ... is not likely to multiply sufficiently to be a problem unless the average temperature exceeds $20^{\circ} \mathrm{C}$ for at least 4 months." Freeman (1974) gives the developmental minimum of $T$. granarium as $19^{\circ}$ to $21^{\circ} \mathrm{C}$. Most grain storage areas of New Zealand have summer 4-monthly average temperatures in the range of $15^{\circ}$ to $20^{\circ} \mathrm{C}$, and so on this basis khapra beetle would not be expected to occur abundantly. Little information is available on grain temperatures during prolonged storage in New Zealand, but if they were higher than $20^{\circ} \mathrm{C}$ for 4 months or longer then economic damage could be anticipated.

New Zealand may therefore be a marginal habitat for khapra beetle. $T$. granarium is a pest of barley and wheat (Howe pers. comm.); it attacks maize but does not do as well on it. Most of New Zealand's wheat, barley, and oats are stored in the South Island, mainly from mid-Canterbury south, where temperatures may limit khapra beetle establishment. In the North Island the area of maize grown has increased considerably in recent years, and stored maize is now the most generally available potential food. In the South Island possible areas for establishment are Blenheim, Nelson, Canterbury, and perhaps warmer parts of Otago.

If khapra beetle established in New Zealand but was not an abundant pest, it could be important for other reasons. It is difficult to detect in small numbers (Howe 1957), it can survive cold or starvation for lengthy periods, it can be difficult to eradicate once established in an area, and it can breed in dry products and could perhaps be of some importance in milk powder production and storage areas.

$T$. granarium has been intercepted entering New Zealand on a range of hosts, including five interceptions from South Africa (Table 1).

Trogoderma variabile Ballion (Col.: Dermestidae)

This species was first intercepted entering New Zealand in 1977 (Table 1). If it established it could become a pest in milk powder factories, stored cereals, and other products. In the U.S.A., populations of $T$. variabile in grain do not build up very rapidly
(Dr R. S. Beal, Arizona University, pers. comm.). Most concern is about its occurrence on products where no degree of infestation is acceptable, e.g. in dried milk processing plants.

$T$. variabile has been intercepted less frequently than $T$. granarium, and mainly from seeds (Table 1 ). At least six larvae of $T$. variabile were obtained from the herbal material intercepted from Greece in 1977 (Mrs C. M. Richardson, pers. comm.). Adults were reared and their identity confirmed by Dr Beal.

Trogoderma variabile occurs in southern Russia and Persia, and more recently it has been found throughout the U.S.A. In March 1977 it was detected at a rice mill at Griffith, New South Wales, and was subsequently found at a few localities in the Riverina rice-growing districts (Anon. 1978).

\section{DISCUSSION}

Many stored-product pests which occur overseas are not yet established in New Zealand. Dermestid beetles, particularly Trogoderma species, possibly represent the greatest risk. These and other pests tolerant of dry conditions could become important contaminants in dried milk production and storage areas, as well as attacking a range of other products. Species capable of attacking wool are also important because of the economic value of this industry to New Zealand. Species of Trogoderma of most concern to New Zealand include $T$. variabile, T. glabrum (Herbst), and T. anthrenoides (Sharp); it is not known how much these species are transported by ships (Howe pers. comm.). T. inclusum LeConte is important as a potential pest of dried milk.

Some potentially important pests occur infrequently in imported produce, and are only occasionally intercepted entering the country. These pests can be difficult to detect, but may be serious if they establish (e.g. species listed in Table 1). Cases of insect and mite contamination are frequently reported from small quantities of produce, and important interceptions have been made from these, and from non-normal host materials. This emphasises the necessity for importers and citizens to report previously-undetected occurrences of insects in imported produce, and for appropriate action to be taken following detection.

The overseas distribution of some species has recently changed or they have become apparent as pests in additional countries, and increased surveillance by quarantine authorities is required to prevent their entry into New Zealand. Pests of this type include Reesa vespulae which appeared in Norway in 1960 and more recently has been reported from Sweden, Denmark, Germany, the U.S.S.R., Afghanistan, and England (Adams 1978); and Trogoderma variabile which has recently occurred in Australia (Anon. 1978). 
The distribution of insecticide-resistant insects through international trade was reviewed by Dyte (1979), who gave details of nine storage pests in which resistance to maldison has been detected. All these occur in New Zealand and seven of them are frequently intercepted entering the country. Insecticide resistance is not yet known to occur in storedproduct insects in New Zealand, and the establishment of resistant strains needs to be prevented for as long as possible. Dyte states that maldison resistance in Tribolium castaneum occurs in 75 countries, including Australia where resistance was detected in 1968. T. castaneum is the most frequently intercepted stored-product insect entering New Zealand, and during the period $1966-72$ it was intercepted seven times from Australia. Further emphasis needs to be given to storage pests during inspection of imported produce if establishment of insecticide-resistant strains is to be prevented.

\section{LOCAL STORAGE PEST PROBLEMS}

\section{Dried milk products}

During the mid-1970's some problems occurred with insects (and mites) contaminating dried milk products after 1 or 2 years storage (instead of the usual storage time of about 3 months). Dairy factories and dairy product storage areas throughout New Zealand were surveyed during April-June 1975 (Somerfield et al. 1980) to ascertain which species were present and were likely to be contaminants. Spray-dried bagged milk powder was the most abundant product at the stores visited. Storage hygiene is normally high at such establishments, and occurrences of insect and mite pests are minimal in relation to the large quantities of products stored.

Thirteen species of insect and six species of mite were identified from factories and stores. These included Anthrenus verbasci (L.) and Anthrenocerus australis (Hope) which are often associated with animal products; Oryzaephilus mercator (Fauvel) which favours products high in fat or oil content; Tribolium castaneum (Herbst) which can survive in dry environments; and ubiquitous or scavenger species such as Ptinus tectus Boieldieu. Recently Anthrenocerus australis has occurred in the sifting area of a casein factory.

\section{Poultryhouses}

\section{Dermestes maculatus de Geer (Col.: Dermestidae)}

Hide beetle (Dermestes maculatus de Geer) has recently been a pest in poultryhouses, where mature larvae making pupation sites have damaged wooden structural materials. Similar damage has been reported from the U.K. and U.S.A. (Josland 1978). In New Zealand D. maculatus has mainly occurred on poultry farms in the Auckland, Waikato, Bay of Plenty, and Gisborne provinces. Cage-brooder houses, wooden wall frames, and roof trusses have been damaged, and severe damage to polystyrene insulation has occurred (Josland 1978). D. maculatus larvae appear to bore more frequently in softer parts of wood.

Various chemical controls have been tried, together with hygiene procedures. These reduced hide beetle numbers, but mature larvae and pupae behind wall and ceiling linings were difficult to eradicate. The most effective control has been the British recommendation to treat empty, cleaned houses with a $2 \%$ iodofenphos wettable powder sprayed at 5 litres per $100 \mathrm{~m}^{2}$ (Josland 1978).

In June 1978 Dermestes maculatus severely damaged tanalised (preservative-treated) wooden poles in a relatively new woolshed and sheepyards at Purerua (near Kerikeri). Adult beetles were present in the poles; the initial source may have been neglected sheepskins. D. maculatus has also recently occurred in opposum (Trichosurus vulpecula (Kerr)) skins at Ngatea, in skins at the Kaiti Refrigerating Company, Gisborne, at a milk powder factory, in meat meal, and in stored dried pet foods.

Alphitobius diaperinus (Panzer) (Col.: Tenebrionidae)

The lesser mealworm (Alphitobius diaperinus (Panzer)) occurs frequently in poultryhouses and poultry manure. Moist grain and spilled poultry feed in the manure possibly favour its occurrence. Since 1976 A. diaperinus has been reported from these situations at Papakura, Hamilton, Hastings, New Plymouth, and Christchurch. Several cases have occurred in broiler houses (Dale et al. 1976); almost one third of the insulation was disintegrated in a 3 yearold house at Patumahoe (South Auckland).

\section{Larvae in carpets}

Hofmannophila pseudospretella (Stainton) (Brown house moth)

On 8 November 1979 it was reported on television that several cases of brown house moth (Hofmannophila pseudospretella (Stainton)) larvae attacking carpet had occurred in Wellington. The programme requested that information on other attacks be referred to the New Zealand Wool Board. Further publicity occurred in the news media, and up to 29 February 1980,250 complaints of moth larvae attacking carpets had been received by the Wool Board. 72 percent (approximately 180) of these were due to $H$. pseudospretella; some infestations by Tinea pellionella $(\mathrm{L})$. and Tineola bisselliella (Hummel) were also reported. Carpets attacked ranged from almost new to 6 years old, with occasional attacks in older carpets. Infestations have been reported from various parts of New Zealand including Auckland, Wellington, and Christchurch. The mild wet winter of 1979 may have allowed high survival rates of eggs and early instar larvae, resulting in an increased incidence of attack on carpets. 
Hofmannophila pseudospretella is stated by Munro (1966) to be an omnivorous scavenger; Woodroffe (1951) refers to it feeding on hides, leather, and fur. Cole (1962) says he found carpets were the household articles most often damaged, especially the edges of fitted carpets when they were folded under.

Meyrick (1883) stated that $H$. pseudospretella "... is very common in houses, probably throughout New Zealand". He observed it at seven localities from Hamilton to Dunedin. Hudson (1928) stated that it " . . is now common and generally distributed throughout the country ...'. He says it is " . . . very destructive amongst carpets...", thus indicating that carpets have been damaged in this country for over 50 years. Since $1970 \mathrm{H}$. pseudospretella has been identified at Plant Health Diagnostic Stations from a range of hosts including carpets and other woollen materials.

Conditions in and around carpets are probably important in predisposing them to attack by $H$. pseudospretella larvae. Darker undisturbed areas (e.g. under heavy furniture and fitments), and seldom used areas of wall to wall carpet may be more prone to infestation. Higher humidities and dampness in basement rooms, near concrete walls and floors, or infrequently disturbed areas may favour attack. Shag-and semi-shag-piled carpets have been infested more frequently than low short-piled carpets. $H$. pseudospretella has also attacked synthetic fibre curtaining and upholstery, and candlewick (100\% cotton) bedspreads. Carpet shampoos and cleaning processes may increase the likelihood of attack if they lower insecticide levels in carpets.

In New Zealand, carpets were until recently treated during manufacture with $0.05 \%$ a.i. 'Eulan' (chloro-2-chloromethyl sulphonamide diphenyl ether). Because this was apparently ineffective against $H$. pseudospretella larvae and possibly others, treatments with 'Eulan' have now been increased to $0.08 \%$ a.i.. Mitin LP (80\% Eulan and $20 \%$ Mitin N (a halogenated diphenylurea)) and permethrin can also be used at recommended rates, but in practice are less frequently employed.

\section{DISCUSSION}

Local investigators, sometimes in association with overseas experts, have worked on controls for these problems. Research is continuing with some, either in New Zealand (Hofmannophila pseudospretella larvae in carpets and other woollen materials), or overseas (Dermestes maculatus in poultryhouses). There are problems associated with the use of insecticides and fumigants on or near stored dried milk products because of the rick of residues reaching unacceptably high levels. Considerable emphasis on hygiene and prevention has been necessary with this type of product. In poultryhouses a very different situation occurs as quantities of infestable residues accumulate continually. Strict attention to hygiene is beneficial, but is costly in time and effort for the producer. The use of non-susceptible structural materials such as steel is beneficial but increases capital costs. With $H$. pseudospretella larvae reliance is placed on insecticidal treatment to prevent attack. Prevention by physical methods is difficult, although a lower frequency of attack has occurred in short, densely-piled carpets.

\section{Acknowledgments}

I thank Mr D. C. M. Manson and Mr J. B. Keall, Plant Health Diagnostic Station, Levin, for providing quarantine and local records of Coleoptera; Dr R. W. Howe, Slough Laboratory, England for information on Trogoderma granarium and other Trogoderma species; Dr R. S. Beal, Arizona University, U.S.A. for information on Trogoderma variabile; Mrs C. M. Richardson, P.H.D.S., Levin for information on an interception of $T$. variabile and on Sphaericus gibboides; Dr C. Page, Wool Research Organisation of New Zealand, Lincoln for advice on chemical treatment of carpets; Mr R. A. Hogg, New Zealand Wool Board, Wellington, for information on Hofmannophila pseudospretella attacking carpets; Dr J. C. Watt, Entomology Division, DSIR, for supplying records from the N.Z. Arthropod Collection, DSIR, Auckland; and Mr J. S. Dugdale, Entomology Division, DSIR, for information on Lepidoptera.

\section{REFERENCES}

Adams, R. G. 1978: The first British infestation of Reesa vespulae (Milliron) (Coleoptera: Dermestidae). Entomologist's gazeete 29: 73-75.

Aitken, A. D. 1975: Insect travellers. Volume I. Coleoptera. Ministry of Agriculture, Fisheries and Food, technical bulletin 31 . London, HMSO.

Anonymous. 1978: Australia: warehouse beetle. Quarterly newsletter, FAO Plant Protection Committee for the South East Asia and Pacific Region 21(1): 3-4.

Cole, J. H. 1962: Hofmannophila pseudospretella (Stnt.) (Lep.: Oecophoridae), its status as a pest of woollen textiles, its laboratory culture and susceptibility to mothproofers. Bulletin of entomological research 53: 83-89.

Dale, P. S.; Hayes, J. C.; Johannesson, J. 1976: New records of plant pests in New Zealand. New Zealand journal of agricultural research 19: 265-269.

Dyte, C. E. 1979: The importation of insecticide-resistant strains of stored-product pests. Annals of applied biology $91: 414-417$.

Freeman, J. A. 1974: Infestation of stored food in temperate countries with special reference to Great Britain. Outlook on agriculture 8(1): 34-41.

Hatch, M. H. 1961: The beetles of the Pacific Northwest. Part III: Pselaphidae and Diversicornia 1. Seattle, University of Washington Press.

Howe, R. W. 1957: How much can the Khapra beetle spread in the U.S.A.? Journal of economic entomology 50: 374-375.

Hudson, G. V. 1928: The butterflies and moths of New Zealand. Wellington, Ferguson and Osborne. 
Josland, P. 1978: Hide beetle: biology, damage and control: in poultryhouses. Aglink FPP 143 (August 1978). Wellington, Media Services, Ministry of Agriculture and Fisheries.

Meyrick, E. 1883: Descriptions of New Zealand microLepidoptera. III-Oecophoridae. Transactions and proceedings of the New Zealand Institute 16: $1-49$.

Mroczkowski, M. 1968: Distribution of the Dermestidae (Coleoptera) of the world with a catalogue of all known species. Annales zoologici 26: 15-191.

Munro, J. W. 1966: Pests of stored products. London, Hutchinson.

Papp, C. S. 1962: An illustrated and descriptive catalogue of the Ptinidae of North America. Deutsche entomologische Zeitschrift 9:367-423.
Somerfield, K. G. 1977: Insects of economic significance recently recorded in New Zealand. New Zealand journal of agricultural research 20:421-428.

Somerfield, K. G.; Manson, D. C. M.; Dale, P. S. 1980: Insects and mites associated with dried milk product storage areas in New Zealand. New Zealand journal of experimental agriculture 8: 83-85.

Waller, J. B.; Watt, J. C. 1979: A record of Reesa vespulae (Coleoptera: Dermestidae) in New Zealand. New Zealand entomologist $7(1): 51$.

Woodroffe, G. E. 1951: A life-history study of the brown house moth, Hofmannophila pseudospretella (Staint.) (Lep., Oecophoridae). Bulletin of entomological research 41: 529-553. 